\title{
Improvement and Innovation of Accounting Major's Education Method
}

\author{
Honghua Wang \\ Continuing Education Center, Zaozhuang Vocational College of Science \& Technology ,Tengzhou \\ Shandong, China \\ 1481534288@qq.com
}

Keywords: accounting major; education; innovation; teaching practice; quality improvement

\begin{abstract}
Accounting major has the characteristics of application and practice, at present, there are some problems in accounting education, such as unreasonable allocation of teaching content, single teaching method and weak application, so it is necessary to improve the teaching method of accounting major. Through the reform and research of the training objectives and concepts of accounting courses, the paper constructs a modular content system combining theory with practice, and gradually explores an effective mode of practical teaching in teaching practice. Combining with the reform direction of accounting major, this paper analyzes the reform of classroom teaching of accounting major. Aiming at the problems in teaching content and teaching methods, this paper analyzes the teaching reform strategy, improves the interest of accounting teaching class, develops multimedia teaching and micro-course teaching, and improves the practicality and interaction of accounting education. The allocation of resources is deepened, so as to improve the input of teachers, promote the improvement of teaching level, and improve the quality of accounting students.
\end{abstract}

\section{Introduction}

Accounting major is the study of how to recognize income and assets in a given business cycle. In addition to preparing financial statements and recording corporate transactions, accountants are more important to participate in corporate mergers, quality management, the application of information technology in finance, tax strategies and many corporate management decisions. Accounting covers a wide range of fields: authentication, auditing, taxation, corporate accounting, management accounting, financial management, bankruptcy liquidation, forensic accounting, budget making, business consulting, and so on ${ }^{[1]}$. Accounting major is a strong application of professional, accounting graduates to learn knowledge should be used in accounting practice. Under the exam-oriented education in the past, the phenomenon of "high score and low ability" existed generally. When the finance and accounting graduates set foot on the job, they had poor practical ability and poor ability of applying knowledge, which made it difficult to adapt to the needs of the society. Companies often complain that it takes a lot of time and effort to train students who have just left school. The accountants trained in colleges and universities should be applied talents who not only master the knowledge of accounting theory but also have the ability to work in finance and accounting. It focuses on vocational skills and practical abilities, but the disadvantages of the traditional teaching mode become more and more obvious ${ }^{[2]}$.

In recent years, education department has carried on the thorough teaching research around the curriculum training goal and the content system, the teaching pattern, the practice teaching, the teaching method and the examination way and so on. Today, with the vigorous development of accounting theory and practice, the speed of accounting knowledge renewal is quickening, and the traditional education mode has not been able to meet the requirements of accounting undergraduate teaching. Therefore, it is necessary to reform and innovate the accounting undergraduate education model. This paper puts forward some suggestions on the undergraduate education mode of accounting major from three aspects: the re-orientation of the educational goal, the re-setting of the curriculum system and the renewal of the classroom teaching methods, in order to provide a 
theoretical reference for the teaching practice, so as to promote our accounting undergraduate education to a new level.

\section{Present situation and reform goal of accounting major}

With the country paying more and more attention to the accounting major in higher education, the enrollment scale of accounting major in higher education expanding day by day. Due to the uneven development of teachers and investment of accounting major in colleges and universities, and the difference of specialty setting, the present teaching situation of colleges and universities highlights a lot of shortcomings, which to a certain extent affects and restricts the development of higher accounting major. Based on the teaching characteristics of higher accounting, this paper discusses how to strengthen the practicality of accounting major and seek an efficient teaching mode in view of the problems in the current teaching process. Finally, the training of accounting technology can meet the needs of society ${ }^{[4]}$. At present, the present situation and characteristics of accounting major in colleges and universities in China are mainly reflected in the following aspects:

\subsection{Objectives and ideas of curriculum cultivation}

The aim of the course training of accounting major is to establish accounting talents with the aim of "ability cultivation and application innovation". In the training of accounting professionals, we should pay attention to the cultivation of students' various abilities, especially the cultivation of students' communicative competence. In practical work, accounting personnel often deal with banks, taxation, industry and commerce, auditing, finance, customers, as well as the leaders, functional departments and employees of their own units. Conflicts and differences will inevitably occur in the exchanges, accounting personnel should make positive efforts to reach a consensus with the other party within the scope of relevant laws and regulations so that the problem can be properly resolved ${ }^{[5]}$.

\subsection{Curriculum content system setting}

Major courses in accounting include: management, accounting principles, financial management, intermediate financial accounting, auditing, cost accounting, management accounting, accounting computerization, advanced financial accounting, management statistics, etc. In order to improve the ability of accounting students to analyze and solve practical problems in various ways, the curriculum system of accounting major has the characteristics of diversity and professionalism. By offering courses in accounting, auditing, financial management, finance and finance, students should master the basic theoretical knowledge of accounting in a systematic and solid way ${ }^{[6]}$. It should cultivate students to have a reasonable knowledge structure close to the market.

\subsection{Practical teaching}

The main form of practice teaching in accounting major is simulated practice training and post training. It is difficult for students to understand the checkout, reconciliation, correction and identification of original vouchers from books. Through practical teaching and practical teaching, the level of computerization of accounting students can be improved at the same time. Through practical teaching, accounting students can count money skillfully, identify counterfeit banknotes, operate computers skillfully, use desktop calculators, and use simple knowledge of accounting English.

\section{Problems existing in the education of accounting major}

At present, the main purpose of accounting major in higher education is to train the technical talents who meet the needs of the society. This needs theoretical knowledge learning, practical teaching, practical skill training and practical experience accumulation and so on. Among them, the practice teaching of accounting major is a very important link, it can promote the effective combination of theory and practice, truly achieve the purpose of training students' accounting major 
teaching practice. Therefore, if we want to strengthen the teaching practice, it is the key to find out the problems in accounting teaching ${ }^{[7]}$.

\subsection{Professional education idea and teaching method of accounting is relatively backward}

Although universities carried out some reform of the teaching mode of professional accounting, but the traditional "Teacher centered" injection teaching mode is the main teaching mode. This teaching mode fully reflects the dominant position of teachers, but the students are placed in the invisible the passive position, only equivalent to knowledge record and accept machinery. The teaching mode of accounting professional classroom teaching atmosphere, classroom efficiency is low, and suppress the accounting students' creative thinking, affect the enthusiasm of students, training has hindered the students' ability of analyzing and solving problems, leading to the students the poor adaptability of the accounting practice ${ }^{[8]}$.

\subsection{Curriculum of accounting major is unreasonable and the teaching content is backward}

The curriculum setup of higher accounting cannot be consistent with the requirement of professional post ability, the practical skill courses and professional courses are short of hours, and the practical operation is just a formality. The quality of textbooks is not high and duplicated, and the content is out of touch with the professional demand because of the poor level of textbook compilers and unreasonable choice of teaching materials. The content of practical training is also simple financial treatment, just financial standard, the continuation of system explanation, lack of practicality and pertinence.

\subsection{Teaching methods of accounting major lag behind, and the practical teaching lacks attention}

The traditional teaching method of accounting major is not only time-consuming and laborious, the content of teaching is limited, but also can only demonstrate simple operation, and cannot combine principle with practice, accounting and analysis organically ${ }^{[9]}$. It cannot meet the needs of accounting knowledge of students at all levels, which makes students lose their initiative in learning. For a long time, many educators believe that practical teaching is only a verification of theoretical understanding and is dependent on theoretical teaching. The quality of teaching mainly depends on the level of theoretical mastery, neglects or does not attach importance to curriculum experiments and practice. Of course, practical teaching is more difficult than theoretical teaching, which is one of the reasons why practice teaching is not paid attention to.

\subsection{Teacher strength and the teaching investment is insufficient}

The teaching staff of accounting major in colleges and universities cannot meet the needs of the development of accounting discipline, and there are few "double-qualified" teachers in real accounting theory and accounting practice. In the course of teaching, the main form of the assessment of students is written examination papers, and the performance is the standard of students' ability evaluation, which seriously affects the cultivation of students' practical operation ability and comprehensive quality, and the teachers' strength is insufficient. The existence of insufficient teaching investment has seriously affected the development of accounting education.

\section{Improvement and innovation mode of accounting education method}

The current accounting education has some problems, such as unreasonable teaching content allocation, single teaching method and weak application, so it is necessary to improve the teaching methods of accounting major, gradually explore an effective practical teaching model. Firstly, the teaching method is reformed, and the learning method of professional accounting is of great effect and high value. Under the guidance of micro-classroom teaching mode, the teaching method of accounting major has changed. The teaching mode of accounting major has been probed into by using the method of micro-classroom education learning, so that the course content can be understood more deeply and the teaching quality can be improved. At present, the common 
accounting education methods based on micro classroom include heuristic education, multimedia education, feedback education and overturn education.

\subsection{Heuristic teaching}

Heuristic education is the usual way of teaching accounting major in classroom education and course content learning. The open teaching method is used to train the professional thinking of accounting major, the ability of accounting major, and the professional training of accounting profession. Combining with the teaching practice of the classroom course of accounting major, this paper carries on the classroom innovation research, enriches the opportunity and the ability of thinking practice with the accounting major. In the classroom practical education link guide the study, promotes the specialized level enhancement.

\subsection{Multimedia education}

As a new type of education method, accounting major has a good effect in accounting education. Multimedia education is used to combine audio, influence, video, projector, recording pen and other educational hardware facilities and electronic equipment. Adopting the method of distance education and control, the classroom education method of accounting major is innovated. Multimedia education is the main technical means of accounting education to improve the teaching ability of accounting major.

\subsection{Feedback education}

Feedback education is a breakthrough and innovation in teaching methods. According to the rich tools and carriers of accounting major learning, teachers and students are promoted to cooperate and communicate in the accounting teaching classroom, so as to improve the teaching and application ability of accounting major. With "micro-classroom" as the core, the students should be guided to study accounting major in a large and flexible way, so as to promote the interest and quality of accounting teaching.

\section{Tactics of Accounting Teaching Reform in Colleges and Universities}

In the research of teaching reform of accounting major, we should take active measures to reform the previous teaching mode, cultivate both excellent professional knowledge and strong operational ability to meet the needs of the society.

\subsection{Changing Educational idea and improving Teaching methods and means}

The educational idea should be changed from the teacher as the main body to the student as the main body of modern education. All teaching activities must take the initiative and enthusiasm of the students as the starting point and get rid of the bondage of the traditional teaching method. Using advanced case teaching method, such as discussion teaching method, problem teaching method, comparative teaching method and discovery teaching method and so on, and widely using modern teaching means such as audio-visual teaching media to stimulate students' interest and enthusiasm in learning, and improve classroom efficiency.

\subsection{Improve the course system and content, strengthen the practical teaching links}

The course contents of higher accounting major should be formulated according to the needs of the market and the employment situation of students, and the new theory can be updated into the curriculum content in time. In addition to strengthening the practical financial practice in the classroom, the school should carefully design and organize the centralized simulated practice, and at the same time, the school should establish an off-campus training base for accounting majors, contact the practice units extensively, and organize students to practice in the actual units, so as to improve the students' ability of integrating theory with practice and solving problems. 


\subsection{Strengthening the Construction of Teachers and establishing a Scientific Evaluation system}

The school organizes teachers to participate in financial training activities related to teaching to improve teachers' practical ability and experience. To change the old assessment methods which take the test results as the main means of assessment, and to establish an evaluation system based on the assessment of students' practical operational ability, problem-solving and innovative ability, social communication ability, moral quality, etc. Truly reflect the students' skill level and comprehensive quality, so that students have a correct and clear understanding of themselves.

\section{Conclusions}

The development of accounting education in colleges and universities cannot be separated from reform and innovation. It determines the quality of accounting education and relates to the ability of accounting talents in the future. Therefore, finding out the problems existing in accounting teaching and exploring positive and effective reform strategies play an important role in improving the teaching quality of colleges and universities. Establish a relatively perfect teaching quality monitoring system and a comprehensive student evaluation system, carry out regular social and graduate follow-up and investigation, understand relevant information about the major, timely feed back to the practice of teaching reform, and effectively regulate and control teaching, so as to promote the innovation of accounting education and improve the teaching quality of accounting major.

\section{References}

[1] Zhang N, Lin X Y, Shi S H. Collaborative filtering recommendation method based on improved heuristic similarity model[J]. Journal of Computer Applications, 2016, 36(8):2246-2251.

[2] Yan Q, Xu L, Shi J, et al. Hierarchical saliency detection[C]//CVPR'13: Proceedings of the 2013 IEEE Conference on Computer Vision and Pattern Recognition. Washington, DC: IEEE Computer Society, 2013:1155-1162.

[3] ULUKUS S, YENER A, ERKIP E, et al. Energy harvesting wireless communications: a review of recent advances[J]. IEEE Journal on Selected Areas in Communications, 2015,33(3): 360-381.

[4] Zhao N, Zhang S, Yu R, et al. Exploiting interference for energy harvesting: a survey, research issues and challenges[J]. IEEE Access, 2017(5): 10403-10421.

[5] Chen Y H, Xiao Y. The development and direction of short-wave communication technology in China[J]. Electronic Technology \& Software Engineering, 2015(7):43.

[6] EZUGWU E S, ADEWUMI A O, FRINCU M E. Simulated annealing based symbiotic organisms search optimization algorithm for traveling salesman problem[J]. Expert Systems with Applications, 2017,77:189-210.

[7] TEJANI G G, SAVSANI V J, PATEL V K. Adaptive Symbiotic Organisms Search (SOS) algorithm for structural design optimization[J]. Journal of Computational Design and Engineering, 2016, 3(3):226-249.

[8] Xiong Q, Zhang Y, Guo M, et al. Performance improvement of MapReduce Shuffle[J]. Journal of Computer Applications, 2017, 37(S1):58-62, 67.

[9] AMOR B B, SU J, SRIVASTAVA A. Action recognition using rate-invariant analysis, of skeletal shape trajectories[J]. IEEE Transactions on Pattern Analysis \& Machine Intelligence, 2016, 38(1):1-13. 